\title{
Effect of urea and polyethylene glycol on chemical composition of pistachio by-products silage
}

A Mokhtarpour, A Naserian, R Valizadeh, A Tahmasebi

Ferdowsi University of Mashhad, Mashhad Islamic Republic of Iran

Email: a.mokhtarpour.m@gmail.com

Introduction Increase in fossil fuel costs and shortage of water sources have increased animal feed costs in many countries. Use of agricultural by-products such as pistachio by-products (PB) as animal feeds is a means of recycling which reduces environmental pollution. Up to 400,000 tonnes/year of this by-product is produced in Iran. Because of its high moisture content and a high level of tannins, ensiling and treating PB with urea and polyethylene glycol (PEG) are potential ways to preserve it and overcome the anti- nutritional effects of tannins. The aim of this study was to evaluate the effect of urea and PEG treatments on deactivation of tannins in PB silage.

Material and methods Fresh PB was collected from pistachio de-hulling factories in Feyzabad (Iran), and samples of these by-products averaging 32\% dry matter (DM) were ensiled for 60 days in 16 plastic buckets with 4 replicates. Four treatments were as follows: Pistachio by-products silage (PBS) as a control, PBS supplemented with urea at 0.1 and $0.5 \%$ of DM, and PBS supplemented with PEG at $1 \%$ of DM. Silage $\mathrm{pH}$ was determined on expressed juice obtained by thorough mixing of $50 \mathrm{~g}$ of fresh silage with $450 \mathrm{ml}$ of distilled water and allowing to stand at $25^{\circ} \mathrm{C}$ for 30 min. This extract was also used for ammonia-N measurement. The $\mathrm{pH}$ of extract was measured using a portable digital pH meter (METROHM 691) and the silage crude protein was analysed by the AOAC (1990) method. Ensiled samples were dried in an oven at $40^{\circ} \mathrm{C}$ and then ground to pass a $2 \mathrm{~mm}$ sieve and $0.5 \mathrm{~mm}$ sieve for tannin assay. Total phenolics (TP) and total tannins (TT) were measured by using the Folin Ciocalteau method (Makkar et al., 1993) and the results were expressed as tannic acid equivalent. Total condensed tannins were determined by the procedure of Porter et al. (1986). Data were analysed statistically using GLM procedure of SAS (9.1) as a completely randomised design. Means were separated by Duncan's multiple range test when a significant $(\mathrm{P}<0.05)$ treatment effect was observed.

Results Silage $\mathrm{pH}$ was increased $(\mathrm{p}<0.05)$ by urea $(0.5 \%)$ addition, but was not influenced by PEG treatment. Adding urea significantly increased the crude protein and ammonia- $\mathrm{N}$ concentrations of silages when compared to the control treatment. Ammonia $\mathrm{N}$ concentration was increased $(\mathrm{p}<0.05)$ by adding PEG. The lowest content of total phenolics, total tannins and condensed tannins were observed in PEG treatment that was statistically significant for TP and TT when compared to other treatments. Addition of urea $(0.5 \%)$ decreased $(\mathrm{p}<0.05)$ TP and TT as compared to the control. Condensed tannins were not influenced by treatments $(\mathrm{p}<0.05)$.

Table 1 Chemical composition and contents of phenolics of ensiled and treated pistachio by-products (g/kg DM)

\begin{tabular}{lllllll} 
& \multicolumn{4}{c}{ Pistachio by-products silage treatment } \\
Item & Control & Urea $(0.1 \%)$ & Urea $(0.5 \%)$ & PEG & SEM & P-value \\
\hline $\mathrm{pH}$ & $4.25^{\mathrm{b}}$ & $4.31^{\mathrm{ab}}$ & $4.34^{\mathrm{a}}$ & $4.25^{\mathrm{b}}$ & 0.024 & $<0.05$ \\
Crude protein (g/kg DM) & $120.1^{\mathrm{b}}$ & $127.5^{\mathrm{a}}$ & $128.7^{\mathrm{a}}$ & $120.2^{\mathrm{b}}$ & 0.82 & $<0.05$ \\
Ammonia-N (mg/dl) & $5.27^{\mathrm{c}}$ & $8.90^{\mathrm{b}}$ & $12.45^{\mathrm{a}}$ & $8.03^{\mathrm{b}}$ & 0.273 & $<0.05$ \\
Total phenolics (TP; g/kg DM) & $99.9^{\mathrm{a}}$ & $94.5^{\mathrm{b}}$ & $93.9^{\mathrm{b}}$ & $89.0^{\mathrm{c}}$ & 1.53 & $<0.05$ \\
Total tannins (TT; g/kg DM) & $51.8^{\mathrm{a}}$ & $47.9^{\mathrm{a}}$ & $43.0^{\mathrm{b}}$ & $34.0^{\mathrm{c}}$ & 1.53 & $<0.05$ \\
Condensed tannins (g/kg DM) & 11.5 & 10.1 & 9.5 & 8.2 & 0.79 & $>0.05$ \\
\hline \hline
\end{tabular}

${ }^{a, b, c}$ Means within a row with different superscripts differ $(\mathrm{p}<0.05)$.

Conclusions These results show that pistachio by-products can be ensiled since it has a relatively low $\mathrm{pH}$ of 4.25 after ensiling. Ensilage and addition of urea and PEG can be effective in deactivation of PB tannins leading to an improvement in nutrient bioavailability.

Acknowledgements Financial support from the Agricultural Faculty of Ferdowsi University of Mashhad is gratefully appreciated.

\section{References}

AOAC. 1990. Official Methods of Analysis, 15th ed. Association of Official Analytical Chemists, Arlington, VA, USA. Makkar, H.P.S., Bluemmel, M., Borowy, N.K., and Becker, K. 1993. Journal of the Science of Food and Agriculture. 61, 161-165.

Porter, L.J., Hrstich, L.N. Chan, B.G., 1986. Phytochemistry. 25, 223-230. 